\title{
SOSIOLOGI DAN ANTROPOLOGI
}
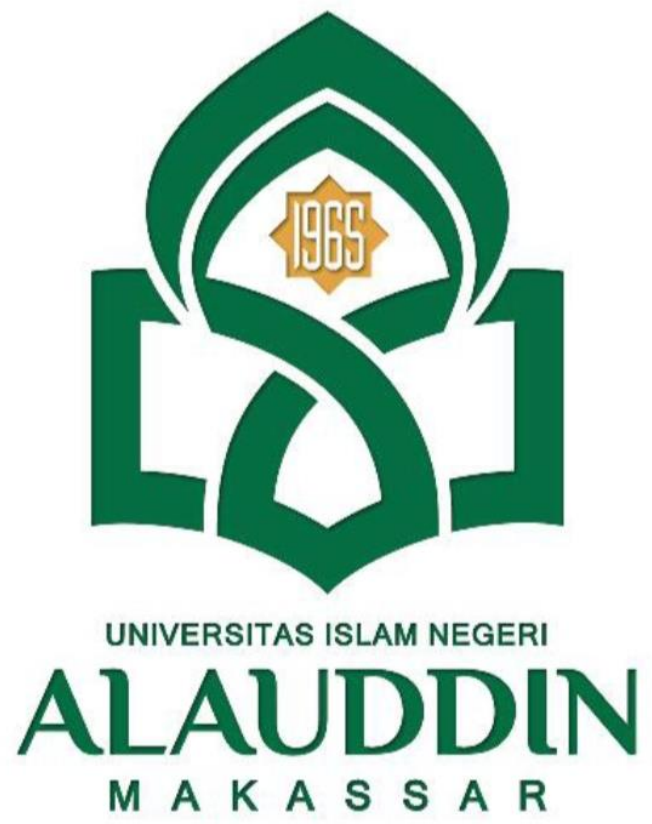

DISUSUN OLEH:

ANDI SITTI NURUL QALBI PUTRI RAZENAL

PRODI KESEHATAN MASYARAKAT

FAKULTAS KEDOKTERAN DAN ILMU KESEHATAN

UIN ALAUDDIN MAKASSAR TAHUN AJARAN 2020/2021 


\section{Pola Budaya Terhadap Makanan dan Gizi}

Kebudayaan adalah seluruh sistim gagasan dan ras, tindakan serta karya yang dihasilkan manusia dalam kehidupan bermasyarakat yang dijadikan miliknya dengan belajar.Dikatakan juga bahwa wujud dari budaya atau kebudayaan dapat berupa benda-benda fisik, sistim tingkah laku dan tindakan yang terpola/sistim sosial, sistim gagasan atau adat-istiadat serta kepribadian atau nilai-nilai budaya.Makanan atau kebiasaan makan merupakan suatu produk budaya yang berhubungan dengan sistim tingkah laku dan tindakan yang terpola (sistim sosial) dari suatu komonitas masyarakat tertentu.Sedangkan makanan yang merupakan produk pangan sangat tergantung dari faktor pertanian di daerah tersebut dan merupakan produk dari budaya juga.Adanya perbedaan pola makan/konsumsi/makanan pokok dari setiap suku atau etnis ; Contoh : orang Timor pola makan lebih kepada jagung, orang Jawa pola makan lebih kepada beras.

Gizi dan Kesehatan

- Kebutuhan bagi setiap inividu dari kalangan struktur baik sehat/sakit,miskin/kaya.

- Semua orang butuh gizi agar status kesehatan baik

- Pembangunan nasional guna terwujudnya kesehatan yang optimal

- Walaupun penyakit tidak biasa ditolak tapi bias dihindari

- Mengonsumsi makanan sehat dalam keluarga 
Masalah-masalah budaya terhadap makanan dan gizi

kebiasaan dan sistim sosial masyarakat terhadap makanan seperti pola makan, tabu atau pantangan, gaya hidup, gengsi dalam mengkonsumsi jenis bahan makanan tertentu, ataupun prestise dari bahan makanan tersebut yang sering terjadi di kalangan masyarakat apabila keadaan tersebut berlangsung lama dan mereka juga belum memahami secara baik tentang pentingnya faktor gizi dalam mengkonsumsi makanan maka tidak mungkin dapat timbulnya masalah gizi atau gizi salah (Malnutrition).

Penyebab timbulnya masalah gizi dipengaruhi oleh berbagai faktor seperti, kemiskinan,kurangnya persedian pangan, sanitasi yang buruk, minimnya pengetahuan gizi dan pola asuh anak,serta perilaku buruk dalam mengonsumsi makanan di kalangan masyarakat. Pola konsumsi makanan sendiri sangat dipengaruhi oleh budaya setempat.

Kalangan masyarakat yang terkena dampak dari sistim sosial atau budaya makan itu berasal dari golongan individu-individu yang termasuk rawan gizi seperti ibu hamil, ibu menyusui, bayi dan anak-anak balita serta orang lanjut usia maka kondisi ini akan lebih rentan terhadap timbulnya masalah gizi kurang.

Pola pikir masyarakat masih beranggapan bahwa kebutuhan makan adalah dengan memakan makanan yang tinggi atau kaya karbohidrat tanpa mempertimbangkan kecukupan gizi yang seimbang ini menunjukkan bahwa aspek sosial budaya masih mendominasi perilaku dan kebiasaan makan yang masyarakat Indonesia. 
Solusi terhadap masalah budaya terhadap makanan dan gizi

Masalah budaya dan makanan kita ketahui dapat menyebabkan masalah gizi yang berdampak pada kesehatan tubuh manusia, sehingga perlu secara cermat untuk memberdayakan masyarakat lokal dengan kearifan dan kecerdasan lokal(local wisdom and local genius) disamping terus melaksanakan penyuluhan gizi sebagai alternative mengatasi masalah budaya dan makanan. Pendekatan yang paling utama adalah melalui perbaikan struktur social masyarakat tentang pandangan mereka terhadap bahan makanan walaupun local tetapi kaya akan nilai gizi. Langkahlangkah yang ditempuh seperti:

1. Perbaikan gizi keluarga dengan melakukan lomba menyiapkan hidangan makanan non beras (kasus budaya Timor),

2. Perbaikan budaya masyarakat dengan pengaruh utama gender terutama ditingkat keluarga.

3. Memperluas areal pertanian dengan menanam berbagai komoditi yang mempunyai nilai gizi tinggi sebagai bahan pangan/makanan seperti kedelai (kasus budaya Jawa).

4. Pemberian makanan tambahan yang bernilai gizi bagi anak-anak balita dan orang lanjut usia.

5. Penyuluhan gizi terpadu dan konsultasi gizi bagi masyarakat.

6. Melakukan pengkajian/penelitian dan riset untuk melihat pengaruh budaya terhadap makanan itu sendiri dengan berbagai implikasi yang terkait didalamnya. 
Pengaruh budaya terhadap makanan

Kebudayaan adalah seluruh sistim gagasan dan ras, tindakan serta karya yang dihasilkan manusia dalam kehidupan bermasyarakat yang dijadikan miliknya dengan belajar(Koentjaraningrat,1990). Selanjutnya dikatakan juga bahwa wujud dari budaya atau kebudayaan dapat berupa benda-benda fisik, sistim tingkah laku dan tindakan yang terpola/sistim sosial, sistim gagasan atau adat-istiadat serta kepribadian atau nilai-nilai budaya. Berdasarkan atas batasan demikian maka dapat dikatakan bahwa makanan atau kebiasaan makan merupakan suatu produk budaya yang berhubungan dengan sistim tingkah laku dan tindakan yang terpola (sistim sosial) dari suatu komonitas masyarakat tertentu. Sedangkan makanan yang merupakan produk pangan sangat tergantung dari faktor pertanian di daerah tersebut dan merupakan produk dari budaya juga. Dengan demikian pengaruh budaya terhadap pangan atau 27 makanan sangat tergantung kepada sistim sosial kemasyarakatan dan merupakan hak asasi yang paling dasar, maka pangan/makanan harus berada di dalam kendali kebudayaan itu sendiri.

Beberapa pengaruh budaya terhadap pangan/makanan adalah adanya bermacam jenis menu makanan dari setiap komunitas etnis masyarakat dalam mengolah suatu jenis hidangan makanan karena perbedaan bahan dasar/adonan dalam proses pembuatan, contoh: orang Jawa ada jenis menu makanan berasal dari kedele, orang Timor jenis menu makanan lebih banyak berasal dari jagung dan orang Ambon jenis menu makanan berasal dari sagu. 


\section{DAFTAR PUSTAKA}

Satrianegara dkk. (2021). Cultural traditional and special rituals related to the health in Bugis Ethnics Indonesia. Gaceta Sanitaria

Ibrahim dkk. (2020). Hubungan Sosial Budaya Dengan Kejadian Stunting Pada Balita Usia 24-59 Bulan Di Desa Bone-Bone Kecamatan Baraka Kabupaten Enrekang Tahun 2020. Public Health Nutrition Journal. Vol. 1, No. 1

Syamsuddin 2018.Dasar-Dasar Penerapan Antropologi Kesehatan, Jakarta,Wade Group. 